\title{
Production of untraditional vegetable juices fortified with fruits
}

\author{
Mona A. Abd El Latif ${ }^{1}$; Hanan A. Abd El Aziz²; Azza A. Kamal El \\ Deen $^{2}$ \\ ${ }^{1}$ Food Technology Research Institute, Agricultural Research Center, Giza,Egypt. \\ ${ }^{2}$ Food Technology Research Institute, Agricultural Research Center, Giza, Egypt
}

\begin{abstract}
This study performed to investigate the possibility of producing some new forms of beverages from taro corms mixes with some fruit juices and milk, evaluating the palatability of those aforementioned taro beverages among the panelists. Those beverages were processed from blanched taro corms only, mixes with mango, guava and strawberry juices and with milk. The chemical components of taro beverages and their treatments ranged between (75.95and77.17\%), (22.82and24.05\%), ((55 and57\%), (0.903and1.656\%), (0.88and5.09\%), (3.65and6.14\%), (33.20and47.8 2\%),(0.089and 0.22 8\%GAE), (5.2and7.1), (0.70and1.40\%), (0.069and0.123 at420nm)and(0.558 and $20.309 \% \mathrm{FW}$ ) for moisture, total solids, total soluble solids, ash, crude fiber, protein, total sugars, total phenols, ph, total acidity, color and antioxidant activity respectively. All products were saved for human consumption after storage for six months at ambient temperature. All taro beverages contain important minerals like potassium, Calcium, iron and zinc. No significant differences were found among the five taro beverages for most of the parameters, except taro milk beverage, also the texture was stabilize after storage for three months. Finally the panelists classified taro beverages as enjoyable.
\end{abstract}

\section{Keywords}

Taro; Fruits; juices; Chemical analysis; Sensory evaluation; Statistical analysis 


\section{INTRODUCTION}

Taro is a plant in the Arum family (Aracea), belonging to the genus Colocasia and species esculenta. It is widely grown in many tropical and subtropical countries for the $u$ se of its corms in food. This plant is known under different names especially in Cylon, $\mathrm{M}$ alaya and Hawaii.(Colocas) is the Egyptian name for taro, which is mostly grown in two horticultural variants. Colocasia esculenta var. Baladi and Colocasia esculenta var. Colocasia esculenta comes in two separate types. Nutritional value and customer acceptance must be evaluated when a crop is being considered for food. A food's nutritional value is determined by its nutritional content and digestibility, as well as the presence or absence of antinutrients and toxic substances. Taro (Colocasia esculenta), a member of the Araceae family, is an old crop grown for its delectable corms and leaves throughout the wet tropics (Ikpeme et al 2010). After yam and cassava, Colocasia is the third most important root crop after tannia (Xanthosomasagitifolium) and is widely farmed in Africa (Obomegheive et al., 1998, Nwanekezi et al., 2010). Global taro output is predicted to reach 9.22 million tonnes on 1.57 million hectares (Ammar et al., 2009). According to Ikpeme et al. (2010), global Cocoyam production was 10.6 million metric tonnes, with 60\% (about 5.8 million metric tonnes) grown in Africa, with Nigeria producing the most. (Ammar and colleagues, 2009). Low in fat (0.5-1.2\%), protein (2.9-4.6\%), and vitamins, but abundant in carbohydrates (90.8-95.5\%) and minerals (1.6-5.5\%), particularly magnesium (32.9-382 mg/100 g), calcium (25.4-192 mg/100 g), and potassium (3.5-59.7 mg/100 g) (Aboubakar et al. 2008; Kaur et al. Njintang et al. 2011). Taro is a good source of fibre, but it also has a lot of gum, which has been shown to aid with high blood pressure, hypercholesterolemia, and diabetes management (Njintang et al. 2011). Taro corms are strong in protein, vitamin $C$, thiamine, riboflavin, 
niacin, and dietary fibre, as well as easily digestible starch, according to studies (Niba. 2003) Calcium, vitamin $E$, and vitamin $B$, as well as magnesium, manganese, copper, and fibre, are abundant in taro. (Enwelu et al 2014) also claim that eating foods high in micronutrients, such as cocoyam, helps the body's utilisation of protein, carbohydrates, and other nutrients. The nutritional value, phytochemical components and ant nutrient contents of taro corm and its products were studied by Richelle et al (2010) they said that Processing taro corm significantly affected its proximate composition, mineral content, photochemical components and ant nutrient (oxalate and phytate) contents. Also, a significant reduction $(\mathrm{p}<0.05)$ was observed in the proximate composition, mineral content, phytochemical components and ant nutrient contents when taro corms were made into powder and were further decreased when processed into taro noodles and cookies. Exposure to high temperature during processing could have greatly affected the reduction in nutrient and phytochemical as well as antinutrient contents of raw taro.

The same researcher discovered the chemical composition of raw taro corm to be Moisture (\%) 6.54 0.16, Crude Ash (\%) 2.44 0.03. Crude Fiber (percentage) 3.01 0.03, Crude Protein (percentage) 7.79 0.03, Crude Fat (percentage) 0.650 .02 , Carbohydrate (percentage) 86.11 0.06, ZINC (mg/100g), IRON (mg/100g), and CALCIUM (mg/100g) were 1.67 0.06, 2.95 0.19, and 55.00 1.64, respectively, whereas Antioxidant (percent n Africa, the Caribbean, the Pacific region, and Asia, Colocasia esculenta, sometimes known as taro or cocoyam, is a common food staple. On a dry matter (DM) basis, the corms have a carbohydrate content ranging from 73 to 80 percent, the majority of which is starch at $77.9 \%$ and 1.4 percent crude fibre. Due to its high carbohydrate content, this tuber is one of the most important sources of energy in various parts of the tropics and subtropics, accounting for around a third of the food consumed by more than 400 people. Taro corms in large quantities, especially if consumed more than once a day, can provide a significant supply of dietary protein. Thiamin, riboflavin, iron, and phosphorus are also found in taro. Cocoyam flour can be used in soups, biscuits, bread, beverages, and puddings. Taro contains a lot of gum, which has been demonstrated to help with high 
blood pressure, hypercholesterolemia, and diabetes control (Habashy and Radwan 1997; Nip 1997).

Food thickeners have been made using taro flour (Onyeike et al. 1995). Because of its mucilage, precooked taro flour has been shown to have a stronger stabilizing effect on fruit juices separation than commercial stabilisers like locust bean gum, carboxymethylcellulose, and carrageenan gum. In their natural condition, taro gum are also thought to be employed as binding and emulsifying agents (Nip 1997).

The goal of this research was to figure out how much food was good for you. phytochemical components, and organoleptic properties of crude taro corms containing $\mathrm{m}$ ucilage or gums as binding and emulsifying agents in order to investigate the possibility o f producing beverages made entirely of taro or taro mixed with fruit juices and milk, as w ell as to assess the palatability of the aforementioned beverages among the panellists.

\section{MATERIALS AND METHODS}

\section{Materials}

A-Taro corms were prepared from agriculture Research Center (ARC) in Giza governorate, Egypt.

B-Milk, sugars, mango, guava and strawberry fruits were purchased from the local market in Giza governorate, Egypt.

C-All chemicals and reagents used in this study were of analytical grade and purchased from El- Gomhoria Company for Trading Medicine and Chemical Egypt.

\section{Technical methods}

Fresh fruit (mango, Guava and Strawberry) were cleaned, washed, blended using blender to obtain fruit juice 


\section{Preparation of taro corms and its beverage products}

The raw taro corms were undergone different physical treatments such as washing, peeling, chopping, before processed. Bring a pot of water to a boil and add a pinch of baking soda. Cut the taro corms in to cubes, boil until it is soft (1520min). Drain and transfer the taro cubes to a large bowl and let them cool. When the taro root is cool, the beverage prepared as follow:

- The first treatment (control) was prepared without (control) any treatment, added $50 \mathrm{gm}$ of cool taro corms, $40 \mathrm{gm}$ sugar and $170 \mathrm{ml}$ water

- The second treatment was mixed $50 \mathrm{gm}$ of cooled taro root, $40 \mathrm{gm}$ sugar, with $170 \mathrm{ml}$ juice from every previous fruits (mango, Guava and Strawberry).

- The third treatment was prepared with $50 \mathrm{gm}$ of cool taro corms, $40 \mathrm{gm}$ sugar and $170 \mathrm{ml}$ milk instead of water. blended all the treatments until became smooth, the obtained final beverage was kept in a bottle, sterilized at $120 \mathrm{c}$ for $25 \mathrm{~min}$, then stored at ambient temperature for analysis.

\section{Chemical analysis}

Moisture content, crude protein, crude fiber, total soluble solids (TSS), ash, pH value and total acidity were determined according to the methods of AOAC (2010). Total sugars were determined using Lane- Eynon procedure as stated in the AOAC (2007). Antioxidant activity was determined by the method of Sheng and Silva (2006). Total free phenols were determined using folin-Denis reagent as described by Swain and Hills, (1959).

Color measurement of non-enzymatic browning was determined according to Ranganna, (1977). 


\section{Determination of minerals}

Minerals ( $\mathrm{Ca}, \mathrm{Fe}$, and $\mathrm{Zn}$ ) were determined using a Perkin Elmer Atomic Absorption Spectrophotometer (Type 2380, Japan), whereas K was determined using a Flame Photometer (model PE P7, England) as described with AOAC (2010).

\section{Microbiological examination}

Total bacterial count was determined according to the method described by Pundir and Jan (2011).

\section{Calculation of nutrition value}

Nutrition value was calculated for protein and minerals as percentage of RDR as follow:

$\%$ protein $=\%$ protein for each product $\times 100$

St of RDR

$\%$ Mineral $=\%$ mineral for each product $\mathrm{x} 100$

\section{St of RDR}

RDR = Recommended Daily Requirement.

\section{Sensory evaluation}

Organoleptic attributes, color, taste, odor, texture and overall palatability were evaluated through ten-point scale, where ten is extremely liked and 1 extremely disliked. Trained panelists were selected from Food Tech. Res. Institute (FTRI), including both male and female members (Lee et al., 2003).

\section{Statistical analysis}

The results (mean \pm standard deviation) were statistically analyzed by analysis of variance (ANOVA) using the statistical package (Costat) software (version 6.311) according to Steel and Torrie (1980). A significant level of $\mathrm{p} \leq 0.05$ was used to indicate a meaningful difference. 


\section{RESULTS AND DISCUSSION}

\section{Physicochemical properties of taro corms.}

Data presented in Table (1) showed the physicochemical composition of fresh taro corms caleulatea on dry weight basis, it could be noticed that moisture content was $73.7 \%$, while ash, crude fiber, fat, protein, total sugar and total acidity were $3.47,3.7$, $2.61,6.68,1.28$, and 0.13 respectively while $\mathrm{pH}$ value was 6.9 .Total phenol (mg GAE/ $100 \mathrm{~g}$ ) was 0.034 , taro is a good source of potassium $(2251 \mathrm{mg} / 100 \mathrm{~g}$ ), while calcium, iron and zinc were 81.5, 2.72 and $1.51 \mathrm{mg} / 100 \mathrm{~g}$ respectively, (Richelle et al 2010 )

Table (1) physicochemical properties and mineral contents of fresh taro corms calculated (on dry weight basis)

\begin{tabular}{|l|c|}
\hline Chemical composition & Taro corms \\
\hline Moisture & 73.7 \\
\hline Total solid (TS) & 26.3 \\
\hline Total soluble solids (TSS) & - \\
\hline Ash & 3.47 \\
\hline Crude fiber & 3.7 \\
\hline Protein & 6.68 \\
\hline Total sugars & 1.28 \\
\hline Total phenols (mg GAE/1oog) & 0.03 \\
\hline PH & 6.9 \\
\hline Total acidity & 0.13 \\
\hline Calcium mg/ioog (ca) & 81.5 \\
\hline Potassium mg/ioog (K) & 22.51 \\
\hline Iron mg/ioog (Fe) & 2.72 \\
\hline Zinc mg/ioog (Zn) & 1.54 \\
\hline
\end{tabular}


Data presented in Table (2)showed the physicochemical composition of fresh mango, guava, strawberry fruit juice and milk .It was clearly observed that mango fruit juice had the high value of TSS (14.23),total sugar (11.37\%) and potassium ( 16.8 $\mathrm{mg} / 100 \mathrm{ml}$ ), while guava fruit juice contained high value of ash, crude fiber and calcium which accounted $0.59 \%, 5.2 \%$ and $16.5 \mathrm{mg} / 100 \mathrm{ml}$ respectively, also strawberry fruit juice recorded high value of moisture content $(88.65 \%)$, total phenol $(1775 \mathrm{mg} / 100 \mathrm{~g})$, total acidity $(0.59 \%)$,iron and zinc( $0.312,0.2 \mathrm{mg} / 100 \mathrm{ml}$ )respectively ,this results nearest with the obtained by (Radwan et al 2015). data presented in Table (2) showed that milk contained high value of ash, protein, calcium, potassium and zinc which being amounted $0.7 \%, 3.4 \%, 119.8,144.9$ and $0.38 \mathrm{mg} / 100 \mathrm{ml}$, respectively.

Table (2) physicochemical properties and mineral contents of fresh mango, guava, strawberry fruit juice and milk.

\begin{tabular}{|l|c|c|c|c|}
\hline Chemical composition & Mango juice & Guava juice & Strawberry juice & Milk \\
\hline Moisture\% & 82.9 & 83.1 & 88.65 & 84.2 \\
\hline Total solid \% (TS) & 17.1 & 16.9 & 11.35 & 15.8 \\
\hline Total soluble solids (TSS) & 14.23 & 9.9 & 8.45 & 8.8 \\
\hline Ash \% & 0.55 & 0.59 & 0.25 & 0.7 \\
\hline Crude fiber \% & 4.15 & 5.2 & 2.69 & --- \\
\hline Protein \% & 0.47 & 0.45 & 0.48 & 3.4 \\
\hline Total sugars & 11.37 & 8.01 & 7.85 & 5.0 \\
\hline Total phenols+ & 804.0 & 629.4 & 775.00 & 0.7 \\
\hline PH & 4.0 & 3.7 & 3.34 & 6.66 \\
\hline Total acidity++ & 0.319 & 0.49 & 0.58 & 0.12 \\
\hline Calcium+++ & 15.88 & 16.5 & 11.0 & 119.8 \\
\hline Potassium+++ & 16.8 & 11.63 & 14.8 & 144.9 \\
\hline Iron+++ & 0.129 & 0.309 & 0.312 & 0.07 \\
\hline Zinc+++ & 0.09 & 0.149 & 0.200 & 0.38 \\
\hline
\end{tabular}

+: $\mathrm{mg} \mathrm{GAE} \mathrm{/} \mathrm{ml}$

$++:$ as citric acid

$+++: \mathrm{mg} / 100 \mathrm{ml}$ 
Table (3) showed the chemical composition of taro beverage and its treatments (on dry weight basis ), from that Table it could be observed that the moisture content of taro, taro mango, taro guava, taro strawberry and taro milk beverages were 76.89, 75.95, 76.32, 77.18, and77.17 \%respectively, also total soluble solids (TSS) for the previous treatments were $55,55,57,55$, and 57\% while ash and crude fiber were (0.903and $0.88 \%)$ for taro beverage, (2.15 and 4.20\%) for taro mango beverages , (2.35and 5.09\%) for taro guava beverage, (2.38 and 3.06\%) for taro strawberry beverage and (2.20 and $0.87 \%$ )for taro milk beverage. Also, taro milk beverage had the high content of protein $(6.14 \%)$ followed by taro strawberry beverage $(5.70 \%)$, taro beverage $(5.47 \%)$, taro guava beverage $(4.37 \%)$ and $3.65 \%$ for taro mango beverage respectively. A slight variation in total sugars was observed between all the beverage products where taro milk beverage had the high content of sugar (47.82\%) while taro strawberry, taro mango and taro guava beverages had the values 45.90. 45.44, and $45.38 \%$ respectively, on the other taro beverage had low percentage of sugar, this variation in total sugars may be related to the high temperature of sterilization which led to the hydrolysis of polysaccharides, hemicellulose and cellulose in all products to monomeric sugars, Hernández et al (2012), reported that temperature and time were the factors that had more effect on the release of reducing sugars. Concerning the percentage of total phenol (mg EGA/100g) they ranged between 0.084 for taro milk beverage and 0.228 for taro guava beverage, the other beverages recorded $0.155,0.133$, and 0.179 for taro, taro mango and taro strawberry beverages respectively. $\mathrm{pH}$ value was 6.4 for taro beverage while it also ranged from 5.2 to 7.1 for their beverage products, total acidity ranged from 0.11 to $1.4 \%$ for the other treatments of beverage products. Results in the same table (3) showed the color of beverage products which ranged from 0.069 to 0.125 for them, concerning antioxidant activity $\% \mathrm{FW}$, results revealed that guava beverage products had the highest value of antioxidant activity than that in the other beverages treatments, it was $20.369 \%$ for its followed by strawberry beverage (15.739\%), mango beverage $(10.739 \%)$, taro beverage 
INTERNATIONAL JOURNAL OF

FAMILY STUDIES, FOOD SCIENCE AND NUTRITION

HEALTH

(4.324\%) respectively, while taro milk beverage had the lowest value $(0.558 \%)$ of antioxidant activity

Table (3) physicochemical properties of taro beverages and their treatments calculated (on dry weight basis)

\begin{tabular}{|l|c|c|c|c|c|}
\hline \multirow{2}{*}{ Chemical Composition } & \multicolumn{4}{|c|}{ Treatments } \\
\cline { 2 - 6 } & T1 & T2 & T3 & T4 & T5 \\
\hline Moisture & 76.89 & 75.95 & 76.32 & 77.18 & 77.17 \\
\hline Total solids (TS)\% & 23.11 & 24.05 & 23.68 & 22.82 & 22.83 \\
\hline Total soluble solid (TSS)\% & 55 & 55 & 57 & 55 & 57 \\
\hline Ash \% & 0.903 & 1.378 & 1.495 & 1.061 & 1.656 \\
\hline Crude fiber \% & 0.88 & 4.2 & 5.09 & 3.06 & 0.87 \\
\hline Protein \% & 5.47 & 3.65 & 4.37 & 5.70 & 6.14 \\
\hline Total sugars \% & 33.20 & 45.44 & 44.38 & 45.90 & 47.82 \\
\hline Total phenols (GAE/100g) & 0.165 & .0 .133 & 0.228 & 0.179 & 0.084 \\
\hline PH & 6.4 & 5.6 & 5.6 & 5.2 & 7.1 \\
\hline Total acidity \% & 0.111 & 1.06 & 0.81 & 1.40 & 0.70 \\
\hline Color (at420 nm) & 0.123 & 0.099 & 0.076 & 0.118 & 0.077 \\
\hline Antioxidant activity (FW\%) & 4.403 & 10.739 & 20.369 & 15.739 & 0.558 \\
\hline
\end{tabular}

T1-Taro beverage, T2-Taro mango beverage T3-Taro guava beverage T4- Taro strawberry beverage 5-Taro milk bevera

\section{Mineral contents of taro beverage and their treatments}

Table (4) showed the composition of elements, calcium (Ca), potassium (K), ), iron $(\mathrm{Fe})$ and zinc $(\mathrm{Zn})$ on dry weight basis. Data in Table (4) showed that beverage product of taro strawberry beverage had the highest amounts of $\mathrm{Ca}(483.26 \mathrm{mg} / 100 \mathrm{~g})$ followed by taro milk beverage $(248.53 \mathrm{mg} / 100 \mathrm{~g})$, taro beverage $(130.66 \mathrm{mg} / 100 \mathrm{~g})$ taro mango beverage $(115.68 \mathrm{mg} / 100 \mathrm{~g})$ while taro guava beverage recorded the lowest value of $\mathrm{Ca}(86.04 \mathrm{mg} / 100 \mathrm{~g})$ Data in the same table (4) showed that all beverages treatments rich in potassium element ,taro milk beverage had the high values of potassium (1100.44 $\mathrm{mg} / 100 \mathrm{~g}$ ), while ranged from 709.26, 588.25, 557.06 and $511.27 \mathrm{mg} / 100 \mathrm{~g}$ for taro 
strawberry taro mango, taro beverage, and taro guava beverage respectively .Iron contents were $3.98,3.26,3.22,1.32$ and $1.225 \mathrm{mg} / 100 \mathrm{~g}$ for, taro mango, taro strawberry, taro guava ,taro milk and taro beverage respectively. In this concern, zinc content was $4.142 \mathrm{mg} / 100 \mathrm{~g}$ for taro guava beverage followed by taro milk (1.32), taro beverage (1.202), taro mango (0.848) and taro strawberry beverage (0.403), respectively.

Table (4) Mineral contents of taro beverage and their treatments (mg/100 $\mathrm{g} \mathrm{Dm})$

\begin{tabular}{|l|c|c|c|c|c|}
\hline $\begin{array}{l}\text { Mineral } \\
\text { contents }\end{array}$ & $\begin{array}{c}\text { Taro } \\
\text { beverage }\end{array}$ & $\begin{array}{c}\text { Taro mango } \\
\text { beverage }\end{array}$ & $\begin{array}{c}\text { Taro guava } \\
\text { beverage }\end{array}$ & $\begin{array}{c}\text { Taro strawberry } \\
\text { beverage }\end{array}$ & $\begin{array}{c}\text { Taro milk } \\
\text { beverage }\end{array}$ \\
\hline $\begin{array}{l}\text { Calcium } \\
\text { (ca) }\end{array}$ & 130.66 & 115.58 & 86.04 & 483.26 & 248.53 \\
\hline $\begin{array}{l}\text { Potassium } \\
\text { (K) }\end{array}$ & 557.06 & 588.25 & 511.27 & 709.26 & 1100.44 \\
\hline Iron (Fe) & 1.225 & 3.98 & 3.22 & 3.26 & 1.32 \\
\hline Zinc $(\mathbf{Z})$ & 1.202 & 0.848 & 4.143 & 0.403 & 1.32 \\
\hline
\end{tabular}

Effect of storage period on microbiological examination of taro beverage and their treatments $(\mathbf{c f u} / \mathrm{g})$.

Fruit juice produced in a sanitary manner has the potential to improve consumer health by reducing the risk of breast cancer, congestive heart failure (CHF), and urinary tract infection. Fruit juice's nutritional richness makes it an excellent medium for microbial development, a carrier for food-borne infections, and associated complications in the absence of adequate manufacturing practises (AI-Jedah and Robinson,2001) Table (5), on the other hand, shows the overall bacteria count of taro beverage items. At zero time, no microbial growth was detected in any of the taro beverage treatments; this could be owing to the beverage's sterilising process during preparation, which lowered the microbial load significantly and increased the shelf-life of the product. After three and six months of storage at room temperature, the total bacterial count, of all beverage treatments increased somewhat, and there was minor contamination. The findings are consistent with those of Silva and Gibbs (2004) and Sampedro et al (2009), who found that fruit juice has a high sugar content and a low $\mathrm{pH}$, which encourages the growth of 
INTERNATIONAL JOURNAL OF

FAMILY STUDIES, FOOD SCIENCE AND NUTRITION

HEALTH

yeasts, moulds, and some acid-tolerant bacteria. In addition, the $\mathrm{pH}$ and moisture level of the food are the most critical criteria that influence the microbial development that causes food to deteriorate (Patriarca et al., 2001). These elements are crucial for spore germination and the growth of bacteria's vegetative cells.

Table (5) Total plate count of product taro beverages (CFU/G)

\begin{tabular}{|l|c|c|c|}
\hline \multirow{2}{*}{ Treatments } & \multicolumn{3}{|c|}{ Storage Period } \\
\cline { 2 - 4 } & Zero time & After 3 months & After 6 months \\
\hline Taro beverage & ND & $2 \times 10^{1}$ & $1 \times 10^{2}$ \\
\hline Taro mango beverage & ND & $2 \times 10^{1}$ & $1 \times 10^{2}$ \\
\hline Taro guava beverage & ND & $2 \times 10^{1}$ & $2 \times 10^{2}$ \\
\hline Taro strawberry beverage & ND & $5 \times 10^{1}$ & $3 \times 10^{2}$ \\
\hline Taro milk beverage & ND & $3 \times 10^{1}$ & $4 \times 10^{2}$ \\
\hline
\end{tabular}

\section{Nutritional evaluation of taro beverages products}

From the Table (6) it could be noticed that $100 \mathrm{gm}$ of tasted taro beverages products provides children aged (3-5) with 19.21 to $32.32 \%$ of protein daily requirements, provides male and female aged (19-35 years) with $6.52-10.96 \%$ and $7.93-13.35 \%$ of protein daily requirements respectively. From the same table (6) it was found that $100 \mathrm{gm}$ of taro beverages products provides children aged (3-5 years) with 8.6o to $48.33 \%$ calcium, 28.40 to $61.14 \%$ potassium ,12.25 to $39.8 \%$ iron and 8.06 to $82.26 \%$ of Zink daily requirements respectively. (DRAs, 2005). while provides male with 8.6 to $48.33 \%$ calcium, 30.99 to $66.69 \%$ potassium, 15.31 to $49.75 \%$ iron and 3.66 to $37.66 \%$ of Zink daily requirements respectively. Concerning female taro beverages products provides them with 8.60 to $48.33 \%$ calcium, 30.99 to $66.69 \%$ potassium, 6.80 to $22.11 \%$ iron and from 5.04 to $51.79 \%$ of Zink daily requirements respectively. 


\section{STUDIES, FOOD SCIENCE AND NUTRITION \\ HEALTH}

VOLUME 4, ISSUE 2, 2021, $124-142$.

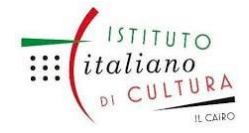

www.egyptfuture.org/ojs/

Table (6) Nutritional evaluation of taro beverage treatments compared to daily recommended requirements for Childrenmales and Females.

\begin{tabular}{|c|c|c|c|c|c|c|c|c|}
\hline \multirow{2}{*}{ Element } & \multicolumn{3}{|c|}{ Daily Recommended Requirements } & \multirow{2}{*}{ T1 } & \multirow{2}{*}{$\mathbf{T} 2$} & \multirow{2}{*}{ T3 } & \multirow{2}{*}{ T4 } & \multirow{2}{*}{ T5 } \\
\hline & $\begin{array}{l}\text { Children } \\
\text { (3-5 years) }\end{array}$ & $\begin{array}{c}\text { Males } \\
(19-35)\end{array}$ & $\begin{array}{c}\text { Females } \\
(19-35)\end{array}$ & & & & & \\
\hline Protein & 19 & 56 & 46 & 5.47 & 3.65 & 4.37 & 5.70 & 6.14 \\
\hline Ca mg & 1000 & 1000 & 1000 & 110.66 & 248.53 & 86.04 & 483.26 & 248.53 \\
\hline K mg & 1800 & 1650 & 1650 & 557.06 & 100.44 & 511.27 & 703.26 & 100.44 \\
\hline Fe mg & 10 & 8 & 18 & 1.225 & 1.32 & 3.22 & 3.26 & 1.32 \\
\hline Zn mg & 5 & 11 & 8 & 1.202 & 0.848 & 4.143 & 0.403 & 1.32 \\
\hline
\end{tabular}

1-Taro beverage 2- Taro mango beverage 3- Taro guava beverage 4- Taro strawberry beverage 5-Taro milk beverage 


\section{Organoleptic evaluation of taro beverage and their treatments}

Tables 7 and 8 indicate the main values of organoleptic evaluation, namely colour, taste, odour texture, and acceptability of beverages made from taro and various fruits (mango, guava, and strawberry) and milk at zero time and after 3 months of storage at room temperature. The results revealed that there were substantial variations in the mean values of colour, taste, odour, texture, and palatability between T5 and all processed taro beverages (T1, T2, T3, T4). The panellists' descriptions of overall palatability ranged from very palatable to palatable for all of the goodsThe results revealed that there were substantial variations in the mean values of colour, taste, odour, texture, and palatability between T5 and all processed taro beverages (T1, T2, T3, T4). The panellists' descriptions of overall palatability ranged from very palatable to palatable for all of the goods It was obvious that the taro milk beverage product received the lowest marks for all sensory characteristics of beverages. After 3 months of storage, it was clear that there were no significant differences in the mean values of all beverages for colour, taste, odour, texture, and palatability, while significant differences were observed between $\mathrm{T} 5$ and the previous beverage in the mean value of odour and texture, finely a slight variation was observed in all processed beverages, and there was no sedimentation and a clear stabilise in the texture of the beverages. This result revealed that the processing of taro beverages and various fruit juices, as well as taro milk, was safe at zero time or during storage at room temperature $\left(25^{\circ} \mathrm{C} \pm 5\right)$. 
INTERNATIONAL JOURNAL OF

FAMILY STUDIES, FOOD SCIENCE AND NUTRITION

HEALTH

Table (7): Sensory evaluation of taro beverage and their treatments at zero time.

\begin{tabular}{|l|c|c|c|c|c|}
\hline Sample & Color & Taste & Oder & Texture & Palatability \\
\hline T1 & $8.8^{\mathrm{a}} \pm 0.632$ & $8.2^{\mathrm{c}} \pm 0.422$ & $8.3^{\mathrm{a}} \pm 0.483$ & $7.9^{\mathrm{ab}} \pm 0.994$ & $8.275^{\mathrm{a}} \pm 0.381$ \\
\hline T2 & $9.05^{\mathrm{a}} \pm 0.369$ & $8.85^{\mathrm{ab}} \pm 0.58$ & $8.55^{\mathrm{a}} \pm 0.832$ & $8.4^{\mathrm{a}} \pm 0.966$ & $8.713^{\mathrm{a}} \pm 0.485$ \\
\hline T3 & $8.7^{\mathrm{a}} \pm 0.675$ & $9^{\mathrm{a}} \pm 0.687$ & $9.1^{\mathrm{a}} \pm 0.568$ & $8.1^{\mathrm{ab}} \pm 1.197$ & $8.725^{\mathrm{a}} \pm 0.65$ \\
\hline T4 & $8.3^{\mathrm{a}} \pm 0.675$ & $8.35^{\mathrm{bc}} \pm 0.669$ & $8.3^{\mathrm{a}} \pm 0.675$ & $8.45^{\mathrm{a}} \pm 0.599$ & $8.35^{\mathrm{a}} \pm 0.503$ \\
\hline T5 & $7.7^{\mathrm{b}} \pm 0.823$ & $7^{\mathrm{d}} \pm 0.527$ & $7.45^{\mathrm{b}} \pm 0.832$ & $7.25^{\mathrm{b}} \pm 0.791$ & $7.316^{\mathrm{b}} \pm 0.444$ \\
\hline
\end{tabular}

T1-Taro beverage T2- Taro mango beverage T3- Taro guava beverage T4- Taro strawberry beverage T5-Taro milk beverage

Table (8): Sensory evaluation of taro beverage and their treatments after storage for 3 months

\begin{tabular}{|l|c|c|c|c|c|}
\hline Treatments & Color & Taste & Oder & Texture & Palatability \\
\hline T1 & $8.28^{\mathrm{a}} \pm 0.994$ & $8.2^{\mathrm{a}} \pm 1.549$ & $8.1^{\mathrm{a}} \pm 1.37$ & $8^{\mathrm{a}} \pm 1.247$ & $8.075^{\mathrm{a}} \pm 1.118$ \\
\hline T2 & $8.9^{\mathrm{a}} \pm 0.876$ & $8^{\mathrm{a}} \pm 1.247$ & $8.2^{\mathrm{ab}} \pm 1.135$ & $8.4^{\mathrm{ab}} \pm 1.265$ & $8.45^{\mathrm{a}} \pm 0.815$ \\
\hline T3 & $8.3^{\mathrm{a}} \pm 1.418$ & $9.2^{\mathrm{a}} \pm 0.789$ & $9.2^{\mathrm{a}} \pm 0.632$ & $8.8^{\mathrm{a}} \pm 0.789$ & $8.8^{\mathrm{a}} \pm 0.896$ \\
\hline T4 & $8.2^{\mathrm{a}} \pm 1.619$ & $8.7^{\mathrm{a}} \pm 0.823$ & $8.7^{\mathrm{ab}} \pm 0.823$ & $8.6^{\mathrm{ab}} \pm 1.35$ & $8.725^{\mathrm{a}} \pm 1.03$ \\
\hline T5 & $7.9^{\mathrm{a}} \pm 1.595$ & $8^{\mathrm{a}} \pm 1.563$ & $8^{\mathrm{b}} \pm 1.563$ & $7.6^{\mathrm{b}} \pm 1.265$ & $7.825^{\mathrm{a}} \pm 1.395$ \\
\hline
\end{tabular}

T1-Taro beverage T2- Taro mango beverage T3- Taro guava beverage T4- Taro strawberry beverage T5-Taro milk beverage

\section{CONCLUSIONS}

The results of this study support the use of taro corms as thickeners, which may help to improve the suspension of other components or emulsions, hence improving the stability of mixed beverages. Moisture, ash, protein, total sugar, calcium, potassium, iron, and zinc are all good sources of natural chemicals, as are various fruit juices and milk. The main ingredients of taro corms, fruit juices, and milk may be investigated for beverage processing. Taro beverage and their treatments with fruit juices and milk showed presence of important compounds and minerals such as calcium, potassium, iron and zinc in a moderate quantity which holds the potential to meet the daily requirement 
from such type of processed beverages. Regarding sensory analysis, no significant differences were found among the five taro beverages studied for most of the parameters, except taro milk beverage which had a moderate overall acceptability. Regarding the overall assessment, consumers classified them as enjoyable, also advice that consumption of taro beverage and their treatments are important for building a strong immune system that help the body to utilize protein, carbohydrates and other minerals (Enwelu et al 2014). Finally, it could be clearly concluded through this study that it is pracatable healthy economic and successful to produce taro beverages. These products were palatable among the panelists

\section{REFERENCES}

Aboubakar, N.Y.N, Scher, J. and Mbofung, C.M.F. Physicochemical, thermal properties and microstructure of six varieties of taro (Colocasia esculenta L. Schott) flours and starches. J Food Eng. 2008; 86:294-305.

A.O.A.C. (2010). Association of Official Analytical Chemists international 19th, ed. Washington, D.

A.O.A.C. (2007). Official Methods of Analysis of the AOAC. International $18^{\text {th }}$ Ed. Gaithersburg, Maryland, USA

Al- jedah, J. and Robinson, R. (2001). Nutritional value and microbiology safety of fresh fruit juices sold through retail outlets in Qatar. P Nutri. 1: 79-81.

Ammar, M.S. Hegazy, A. E. and Bedeir, S.H. (2009). Using of taro flour as partial substitute of wheat flour in bread making. World Journal of Dairy and Food Science, 4 (2) pp. 9-99

Conference of Nigerian Institute of Food Science and Technology (NIFST) (1998), pp. 131-132 
DRI (2005). Dietary Reference Intakes for potassium, sodium and protein. Food and Nutrition Board, Institute of Medicine, The National Academic Press, Washington DC.USA.

Enwelu, I. A. Asogwa, N. P. Nwalieji, H. Um and Ezeano, C. I. (2014). Assessment of Constraints to Cocoyam Consumption in Selected Communities of Enugu State, Nigeria. IMPACT: International Journal of Research in Applied, Natural and Social Sciences (IMPACT: IJRANSS)

Habashy, H.N.and Radwan, H.M. (1997) Chemical, physical and technological studies on Egyptian taro. Ann Agr Sci 42:169-185.

Hernández, J.C.G. Rosales, L.F. Jaramillo, M.A.Z. Navarrete, M.A.N. Villa,J.C.V. Corona, R.M. 1 Ma. Parga, D.C. C.C. and Antonio Peña, A. (2012). Chemical Hydrolysis of the Polysaccharides of the Tamarind Seed. J. Mex. Chem. Soc. 56(4), 395-401

Huang, C.C., Chen, W.C. and Wang, C.C.R. (2007). Comparison of Taiwan paddy- and upland-cultivated taro (Colocasiaesculenta L.) cultivars for nutritive values. Food Chem102: 250-256.

Ikpeme, C.A.E. Osuchukwu, N.C.and Oshiele, L. (2010). Functional and sensory properties of wheat (Aestium triticium) and taro (Colocasia esculenta) flour composite bread. African Journal of Food Science, 4 (5) , pp. 248-253

Kaur, M. Kaushal, P. and Sandhu, S.K. (2011). Studies on physicochemical and pasting properties of Taro (Colocasia esculenta L.) flour in comparison with a cereal, tuber and legume flour. J Food Sci Technol. doi:10.1007/s13197-010-0227-6

Lee, J.Y. H.J. Park, C.Y. Lee and Choi,W.Y. (2003). Extending shelf life of minimally processed apples with edible coatings and antibrowning agents. Lebensm.-Wiss. U. - Technol. 36:323-329

Niba, L. (2003). Processing effects on susceptibility of starch to digestion in some dietary starch sources. Int. J. Food Sci. Nutr. Vol. 54: 97-109.

Nip, W.K. (1997). Taro. In: Smith DS, Cash JN, Nip WK, Hui YH (eds) Processing vegetables, science and technology. Technomic Publishing Co., Inc, Pennsylvania, pp 355-387

Njintang, Y.N. Boudjeko, T. Tatsadjieu, N.L. Nguema-Ona, E. Scher, J.and Mbofung, C.M.F. (2011) Compositional, spectroscopic and rheological analyses of mucilage 
isolated from taro (Colocasia esculenta L. Schott) corms. J Food Sci Technol. doi:10.1007/s13197-011-0580-0 [PMC free article] [PubMed]

Nwanekezi, E.C. Owuamanam, C.I. Ihediohana ,C.V.and wouno,C.I.(2010). Functional, particle size and sorption isotherm of cocoyam cormel flourPakistan Journal of Nutrition, 9 (10), pp. 973-979

Obomegheive, A.A. Obafemi, M.O. and Oyibo, S. (1998). Processing parameters of cocoyam flour production.Proc. 22nd Annual

Onyeike, E.N. Olungwe, T. and Uwakwe, A.A. (1995). Effect of heattreatment and defatting on the proximate composition of some Nigerian local soup thickeners. Food Chem 53:173-175.

Patriarca, A. Vaamonde, G. Fernandez, V. Comerio, P. and Comerio, R. (2001). Influence of water activity and temperature on the growth of Wallemia sebi: application of a predictive model. International Journal of Food Microbiology 68: 61-67.

Pundir, R.K, and Jain, P.A. (2011). Gualitative and quantitative analysis of Indian bakery products Journal of Agricultural Technology,7 (3): 751-762.

Radwan, H. M. E. Rizk Ayat and A. Hareedy Lobna (2015). Production of high quality products by simple technique from soft dates (Hayani and Amhat) at rutab stage. Egypt. J. Agric. Res. 93(4 C): 999 -1011

Ranganna,S. (1977). Mannal of Analysis of Fruits and Vegatable products. Tata Mc Graw - Hill publishing corr cary, New Delhi.

Richelle, M. A. Wilma, A. H. and Erlinda, D. (2013.The Nutritional Value and Phytochemical Components of Taro [Colocasia esculenta (L.) Schott] Powder and its Selected Processed Foods. Journal of Nutrition \& Food Sciences. Volume 3 • Issue 3Top of Form

Sampedro, F. Geveke, D. Fan, X. Rodrigo, D. and Zhang, Q. (2009). Self-lifestudy of an orange juice milk based beverage after pef and thermal processing. J. Food.Sci., 74 (2): S107-S112.

Sheng, S. M. N. and J. L. Silva (2006). Antioxidant activity, anthocyanins and phenolics of rabbiteye blueberry (Vaccinium ashei) by-products as affected by fermentation. Food Chemistry, 97(3): 447-451. 


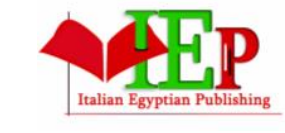

ISSN: $2735-5381$

\section{INTERNATIONAL JOURNAL OF \\ FAMILY STUDIES, FOOD SCIENCE AND NUTRITION \\ HEALTH}

VOLUME 4, ISSUE 2, 2021, $124-142$.

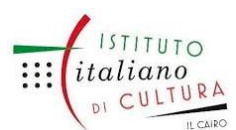

www.egyptfuture.org/ojs/

Silva, F. and Gibbs, P. (2004). Target selection in designing pasteurization processes for shelf - stable high -acid fruit products. Crit. Rev.Food Sci. Nutr. 44:353-360

Soudy, I.D. Delatour, P. and Grancher, D. (2010). Effects of traditional soaking on the nutritional profile of taro flour (Colocasia esculenta L. Schott) produced in Chad. Revue Méd Vét 1: 37-42.

Steel, R. G. and Torrie, T. H. (1980). Principles and procedures of statistics. Abiometrical approach. McGraw Hill Book Comp., Inc., New York, USA.

Swain, T. and Hillis, W.E. (1959). The phenolic constituents of prunes domestic. 1- the quantitative analysis of phenolic constituents, J. Sci. Food. Agric., 10:63-68. 